\title{
In the Name of Welfare: \\ Interest Encounter Through The CSR Programs by PT. BADAK LNG in Bontang, East Kalimantan
}

\author{
Pangeran Putra Perkasa Alam Nasution, M.A, Nur Anggraeni, M.A., Mochammad Wahyu Ghani, \\ M.I.Kom. \\ Doctoral Program of Humanities Studies, Department Anthropology, Department Communication \\ Faculty of Cultural Sciences, Gadjah Mada University, and Faculty of Communication Science, Padjajaran \\ University \\ Sleman-Jatinangor, Indonesia \\ Email: pangeran9688@gmail.com
}

\begin{abstract}
CSR or Corporate Social Responsibility is a program conducted by companies or business entities that exploit natural resources to improve the welfare of the community where the company operates. In Indonesia, corporate social responsibility (CSR) is strictly regulated in Law Number 25 of 2007 about Capital Investment and Law Number 40 of 2007 about Limited Liability Company. Why PT Badak LNG as one of the exploration company of liquefied natural gas resources which operated in Bontang City is important to studied? One such idea is crucial because this company through CSR programs becomes an arena of interest encounters between the local government and the community. PT Badak LNG as the only gas company in East Kalimantan has undertaken the CSR and community development programs since 1984. The focus of CSR implementation is to promote and develop the Bontang society in the socio-economic sector facing post-oil and gas conditions through infrastructure development, community empowerment and promoting the people education in Bontang.

The long duration of CSR programs conducted involving a wide range of potential socio-economic tensions in many places but can be managed by these gas companies without neglecting the development of Bontang City, the geographical features of the ongoing phenomenon. This CSR study was conducted in 2010 in Bontang City, East Kalimantan Province. The approach in this study refers to a phenomenological approach that used qualitative data as the basis of description. The main research methods used were literature study, semistructured interview and observation.
\end{abstract}

Keywords-CSR programs; corporate and government; community welfare; interests encounter.

\section{INTRODUCTION}

The discussion on the implementation of 'Corporate Social Responsibility' programs, especially in natural resource exploration companies in Indonesia, is not something new and always become strategic review issue (Waagstein, 2011). Many experts provide their own definitions of CSR terms. According to Susanto (2009), there are at least 4 reference definitions to CSR, namely: 1) Maignan and Ferrel (2004) defined CSR as "A business acts in socially responsible manner when its decision and actions account for and balance diverse stakeholder interest". This definition emphasizes the need for attention to the balance between diverse stakeholder interests in any decisions and actions undertaken by business actors through socially responsible behavior; 2) The European Commission made a more practical definition of how a company voluntarily contributes to a better society and a cleaner environment; 3) Elkington (1997) argued that a company that demonstrates its social responsibility will pay attention to improving the quality of the company (profit), the community, especially the surrounding community and the environment; (4) The Jakarta Consulting Group put forward the definition of social responsibility is directed both inside (internal) and outside (external) company.

To date, discussions on CSR have evolved in line with the transition of its implementation approach, from 'caritative' and voluntary to 'collaborative' and mandatory actions temporarily. The transition of perspective in the implementation of CSR has not escaped the ongoing debate over the past two decades (Matten dan Moon, 2008:409; Waagstein, 2011:455-56).

In Indonesia, the debate over whether CSR implementation is voluntary or mandatory? Apparently also appear through the rules of CSR implementation in Indonesia as stipulated in Law Number 25 of 2007 on Investment, and in Law Number 40 of 2007 on Limited Liability Company. The minutes that regulate the implementation of CSR in the two laws are inseparable from the mandate of the 1945 Constitution on the national economy and social welfare that the State should 
regulate for the welfare of the people. Not only that, the CSR program is regulated in such a way through the applicable law in Indonesia, also intends to prevent and reduce the environmental damage caused by the operational activities of a company that tends to be deemed not to pay attention to the environmental conditions and the surrounding community (Amri, 2008; Fajar ND, 2010; Suharto, 2006, 2007).

Similarly that experienced by PT. Badak LNG as a liquefied natural gas exploration company which operates in Bontang, East Kalimantan Province, Indonesia. The development of society in Bontang and the progress of Bontang City itself cannot be separated from the CSR programs implemented by PT. Badak LNG. Development that was done by the local municipal government also received a lot of assistance from the gas company. For example, assistance in the construction of roads in the city; provision of traffic signs; improvement of public facilities such as traditional markets, and so forth. It can even be asserted that almost all public facility development activities in Bontang City are related to the assistance provided by the company.

However, along with various CSR implementation by PT. Badak LNG dedicated to the welfare of the community, it loosens up its control over claims of public facilities that are used by the public in general in Bontang. When CSR activities are obligative and require collaboration between company and local government, the collaboration is a means for local municipal government to claim the implementation of CSR programs as a form of public service performance by the government. This subject will be discussed and described further in this article.

\section{METHODOLOGY}

\section{A. The Study Area}

The explanation in this article is a representation of a critical anthropological study on CSR implementation by PT. Badak LNG which operates in Bontang, East Kalimantan Province, Indonesia. Not only trace the role of PT Badak in the implementation of CSR but how local municipal government and community response to the implementation of CSR programs by the PT. Badak LNG in Bontang City that was descriptive entity which composes the entire representation of the study in this article.

The study area covered three districts in Bontang City, namely South Bontang, West
Bontang and North Bontang. However, the South Bontang district, particularly the Berbas Tengah sub-district was the main research area because it is known to receive the most frequent CSR program assistance, the first circle of social assistance recipients determined by the company. The office area and most of PT Badak LNG operating areas are also located in South Bontang District.

\section{B. Research Methods}

The data presented in this paper were gathered through a variety of methods, including: open ended interviews and observation trips with the corporate and government parties also the people who involves in implementation the CSR programs. Here the researcher focuses on the form of CSR programs on certain aid programs, such as education assistance, infrastructure assistance, religious aid, and community empowerment assistance. The determination of the elaboration focus on some of the aid programs relates to the larger amount of funds spent on other programs, such as artistic, youth and other assistance.

The data used as the basis of analysis was a qualitative data. The series of data were analyzed through phenomenological mode to reveal the 'awareness bonding' to the implementation of CSR programs between corporations, governments, and communities, thereby showing CSR slots wherever the various interests met and claimed shuttling.

The term 'phenomenology' becomes increasingly clear after Hegel proposed his idea of the definition of phenomenology as described by the following Ahimsa-Putra: ".....knowledge as it appears to consciousness". In addition, phenomenology is also defined as "the science of describing what people see, what they feel and know in their immediate awareness and experience. This emphasis on the process of depiction leads us to the effort to express the phenomenal consciousness through science and philosophy, to the absolute knowledge of the absolute. (Ahimsa-Putra, 2012:273).

\section{DISCUSSION}

\section{About City, Community, and Company}

Dense and lush green tropical forests, winding rivers and bluish-color sea water provides an incredible admiration for scenic connoisseurs on a plane journey to a small town in one of Indonesia's richest provinces, Bontang City in East Kalimantan. However, it is not as perfect as the 
beauty of Bontang with its special natural scenery. A large company stands magnificent, refineries; tankers are anchored, and the typical torch scenery. Everything is getting more beautiful when seen at night, the ornate lights shining bright like a star cluster was shining in the night sky. Within 30 years, this city has grown very rapidly. Initially, Bontang is not a bustling city with multicultural populations and cultures.

Bontang community is a diverse and multiethnic community. We will be able to find Javanese, Bugis, Papua, Medan, even Timor, and so on. This diverse society that makes Bontang become an increasingly rich city of diversity. Because the location is far from the island of Java and the cost of living is not cheap in Kalimantan, all the prices of basic goods both clothing, food, and house to be very high.

Bontang City is located $150 \mathrm{~km}$ in the north of Samarinda. With a relatively small area compared to other districts in East Kalimantan $(406.70 \mathrm{~km}$ ${ }^{2}$ ). Bontang plays an important role in the development of East Kalimantan and national development. In this city of about 110,000 people, there are two international companies namely PT Badak LNG in South Bontang and PT Pupuk Kaliamantan Timur in North Bontang.

Bontang City is administratively developed as an Autonomous Region since 1999, as it was previously in the administrative area of Kutai Kertanegara Regency. The location is quite strategic, on the Trans-Kalimantan road axis and through the Makassar Strait shipping line so it is advantageous in supporting the interaction of Bontang City with the area outside Bontang City. Overall, the total area of Bontang City reaches $49,752.56 \mathrm{Ha}$, of which most are waters, while the land area is about $29 \%$ or 14,870 ha (Source: Bontang City Government, 2000).

Administratively, Bontang City was originally an administrative city of Kutai Regency and became an Autonomous Region based on Law Number 47 of 1999 about the expansion of province and regency, then divided into 2 districts, North Bontang and South Bontang. North Bontang consists of 4 villages, Lok Tuan Village, Bontang Baru Village, Bontang Kuala Village, and Belimbing Village. South Bontang consists of 5 villages, namely Sekambing Village, Brebas Pantai Village, Brebas Tengah Village, Tanjung Laut Village, and Satimpo Village. City boundary covers Northside with Sangatta district - East Kutai Regency; Eastside with Makassar Strait; Southside with Marangkayu district -
Regency Kutai Kertanegara; West side with Sangatta district - East Kutai Regency

Bontang City is dominated by flat, sloping, and slightly hilly terrain with the altitude between 0 $106 \mathrm{~m}$ above sea level, with slope mostly between $2-40 \%$ with an area of 7,211 $\mathrm{Ha}$. The dominant area (48\%) is the coastal area that forms the relief Bontang City looks horizontal in the coastal areas and hilly in the south to the West.

There is no sufficient historical data about who preliminary discovered this city. There are different opinions and stories, such as the Bugs tales that their ancestors were the initial to discover this city after sailing from the island of Sulawesi. This may be based on the fact that the distance between Kalimantan and Sulawesi is not too far away because it only crosses the Makassar Strait. This assumption makes the Bugis feel powerful in this city because of a sense of ownership that is not legalized.

It is generally known that the indigenous tribes live on the island of Kalimantan are Dayak tribe, but none of the stories support the Dayak people is the local ethnic that became the embryo of the settlement of Bontang City. During the last 30 years, the Dayak existence was replaced by Bugis and Javanese. The Dayaks begin to move to other areas and leave Bontang.

Otherwise, there must have thought that Bontang was found and built after the discovery of the liquefied natural-gas resource's spot in the area of Muara Badak. A strong version says that the city was once under the rule of the Kutai Kingdom. According to historical records, in 1920, Bontang which originally was a village turned into a sub district and then called Onder District van Bontang. Bontang District is led by an assistant wedana under the Kutai Kartanegara Sultanate based in Tenggarong. Furthermore, in 1960 the role of the government of Kutai Sultanate was abolished, and Bontang became one of 30 subdistricts under the Second-Level Regional Government of Kutai Regency.

Over time, this city became one of the cities to be reckoned with. Progress is not only involving one party or some particular parties, but because of the cooperation of many parties who feel like to advance the city with motto "PARK" as an acronym of Orderly, Safe, Mandiri, Religion, Comfortable. Compared to other cities in Indonesia, Bontang is one of the cities that can be said to be independent. All aspects of the problem can be solved alone, and the city is still able to donate foreign exchange to the country. 
This is then a topic that attracts the author's attention to study. The rapid development of Bontang City over the last 30 years involves many responses and community appraisals during the construction. They're so many changes that have impacted specifically on the people and the Bontang City Government. The rise and development of Bontang City cannot be separated from the role of big companies that stand there. These companies directly support and are responsible for providing livelihoods to the Bontang community and the development of Bontang City itself. These companies provide assistance and take part in the ability to make Bontang better. This is obvious and evident to the amount of aid received by the Bontang community, such as support for mosque construction, roads, markets, and educational assistance. All of it strung in the CSR program that can be said as social engineering for the welfare and improvement of the quality of people lifes in Bontang.

PT Badak LNG is a company that has a long history from the start of the establishment to achieve success as it is now. Some stories from the retired former worker explain that in the present the company has grown very rapidly, not as it used to be when it started. The company is now more advanced and become a pride when the company can contribute and assistance to the City of Bontang in particular and Indonesia as a country. Started from two train A and B which was built on November 26, 1974, now PT Badak LNG has operated eight trains, but only six trains still active until now (in 2010). A train is a place and tool at the company's refinery to produce and process raw liquefied natural gas and then converted into LNG and LPG. The LNG refineries owned by PT Badak LNG is located in South Bontang District, East Kalimantan, with a total area of 2,010 Ha.

On July 5, 1977, LNG production capacity reached 3.3 million tons/year, followed by $\mathrm{C}$ and D train which started production in 1983. In 1989 $\mathrm{E}$ train started production, followed by $\mathrm{F}$ train in 1993, 1997 by train G and train H in 1999. Total production capacity of eight trains reached 22.5 million tons/year. LNG production is supported by other facilities in the form of processing units such as LPG cooling units, LNG and LPG storage tanks, steam power plants, LNG loading ports and LNG/LPG loading ports. The LNG refineries were inaugurated in 1977 with the first shipment being made about a week after the use of the Aquarius LNG tanker with the destination to Senboku
Japan. Currently, in 2010, the asset value of the Badak LNG refineries managed by PT Badak LNG reached a value of USD 2.3 billion.

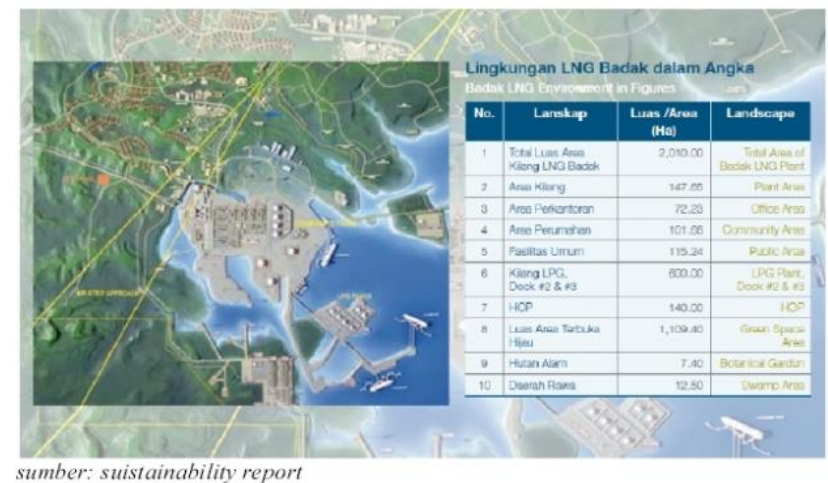

Figure 1. Map of PT. Badak LNG refinery

\section{CSR by PT Badak LNG in Bontang}

CSR implementation by PT Badak LNG has been done since 1984. CSR implementation in the form of social assistance is part of community development or known as 'comdev'. One of the objectives for the social role of the company to the surrounding community is getting better organized. It is also hoped that with the implementation effort of the program there will be a mutual relationship of mutual benefit among various stakeholders and the realization of the company's desire to live forward with the community. Community development implementation is based on funds allocated by the company itself and not the result of production profit.

The vision of PT Badak LNG community development is a sustainable development agent with sustainable development to support the company vision. The company's community development missions are play an active role in community development, foster harmonious relationships with stakeholders, develope the environment to achieve a civil society in supporting the company's operations. This vision and mission are then used by the company as a guide to foster harmonious and beautiful relationships with the community and environment in support of the operation of the LNG refineries. Community empowerment programs are developed as an effort to improve human resources and regional economic growth for better welfare of the surrounding community.

The strategies of community development by PT Badak LNG are as follows: 1) Reduce social inequality through direct assistance that gives rise to multiplier effects; 2) Support the quality improvement of human resources to encourage the realization of an independent society; 3 ) 
Encourage the growth of the real sector economy through partnerships; 4) Establish and maintain two-way communication with communities, municipalities, NGOs and mass media and other stakeholders; 5) Support four pillars of Bontang City government: "Bontang Sehat 2008"; "Bontang Cerdas 2010"; "Bontang Lestari 2010"; "Bontang Bebas Kemiskinan 2010."

Based on community development strategies, PT Badak LNG can be seen a concept of application of social capital created by the company to conduct the process of community development in order to get the sympathy and concern of the community indirectly. The strategy seems to be aimed at an effort to meet the needs of the Bontang community in general. The essence of the strategy implemented by PT Badak LNG is all efforts in the fulfillment of the needs intended to Bontang community become more independent and can be better in the economic competition in the present.

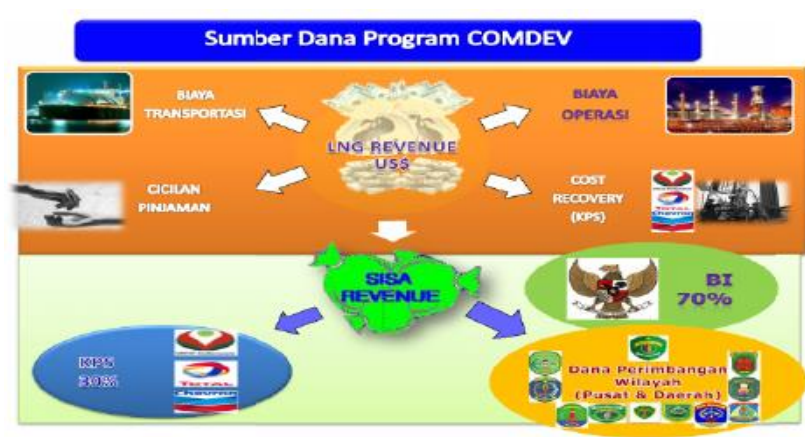

Figure 2. Community Development Source of Funds (Doc. Source: Public Relation of PT Badak $L N G)$.

Community development by PT Badak LNG is focused on several target areas, namely Infrastructure, Education, Community Empowerment, Religious, Health, Sports, Arts, Culture, Youth and Government \& Community Relations. The main focus of the program is improving the quality of human resources and education. With this main focus, it is hoped that the community will be realized independently and also to encourage the readiness of the community around the possibility of Bontang post oil and gas condition. In Corporate Social Responsibility (CSR) implementation, the company designs programs that are able to encourage self-reliance and improve the living standard of the community. The implementation of PT Badak LNG CSR Program is done directly or indirectly.

\section{Infrastructure Assistance}

Implementation of CSR or 'community development' in the form of infrastructure assistance is a physical building object. The assistance that the company has provided in the field of infrastructure were Perintis Road in East Kalimantan, infrastructure improvements at waste processing plants, seawater drying places, cleanliness infrastructure and beauty of the city (gate, park), clean water facilities for the community in general.

The social assistance program in the form of infrastructure is the first community development program undertaken by the company. The community development-infrastructure project began with the construction of a traditional market. This market is a relocation of a burned market. Initially, when the Lincoln market was burn, which was a small market near the company's location. The company saw that the location of the Lincoln market that was too close to the plant that very risky in case of fire. Therefore, as a substitute in 1986 the company built Rawa Indah Market in an area that was originally a swamp area. Rawa Indah market is located in South Bontang District.

Rawa Indah Market development was followed by other programs to help traders and communities who will shop at the market. Cooperation was done with Mulawarman University to develop the potential of human resources, especially the traders. To attract the interest of traders and buyers, the company built an access road to the market, which is Jalan Beringin. The access road was built so that not only residents who live outside the residential complex Bontang companies that shop to Rawa Indah Market, but also the wives and workers of the company. The company worked hard to direct the workers' families to shop there, and downplay the role of the Commissary, a shop in the neighborhood of PT Badak LNG that provided all food and clothing needs for PT Badak LNG workers and their families. The goods already available in the market, from rice, vegetables, and meat, will not be provided again in the Commissary, and until now Rawa Indah market is growing big and providing a complete basic needs.

Other infrastructure programs that are collective, such as a village renovation program conducted in the village of Berbas Tengah. The program was conducted in 2008, it was not only fully by the company but also involved local government and local people. The company provided assistance in the form of materials or basic building materials, and the energy used was derived from local residents. To implement this 
program, all matters about systematic implementation were offered to the selected contractor and the company only oversaw the activities. Village renovation program is done as a form of corporate awareness of the surrounding environment, especially the location that is very close to the company.

In addition, the construction of neighborhood security posts to maintain the security of the region. The repairment of public wells where ordinary citizens perform daily activities, especially housewives, such as taking the water and washing clothes. The development of sports facilities in the form of futsal field that can be used to perform other sports and used for other events, such as wedding ceremony, celebration of Independence Day of Indonesia, and so forth.

There is also the construction of houses for the Berbas Tengah Village community, their houses were built on swamps and made into stilt houses. Initially, all the houses shaped the same and the same color, but gradually people began to innovate to form the house as they wish, as there is a change of paint color and interior of the house.

Furthermore, there is also the construction of clean water facilities. Near the Baru Village football field, Berbas Tengah, there is a free water facility for Bontang community provided by the company. This facility has been available since a few years ago, and may be used by anyone but not for the family of company workers. Near the football field and the place where the clean water was set up the company's security post, people used to call it Baru Village's 'security post'. This post is in charge of watching every person and vehicle that goes in and out of the company area. From this post, it can be seen the activities of people who are taking the water.

The water can be taken by anyone. Each person is given the freedom to take as many as they want. Not infrequently, many people use the vehicle to the location of clean water facilities. Mostly, they use motorcycles, but some also use cars. If people use a motorcycle, they usually come and leave the site approximately more than three times. They come and come home after a full container of water, then come again, then come back again, and so on until they feel enough..

Water containers are usually from the former gallons of bottled water, water jerry cans and others who take it with a bucket. People have their own way when they finish taking the water, they will cover the water container with plastic and rubber so that water does not leak and drip out, then closed with a real container cover. The situation of taking the water is very orderly, they do not fight each other and understand each other because during the taking of water there is no commotion and it appears some of them welcome others to first take water.

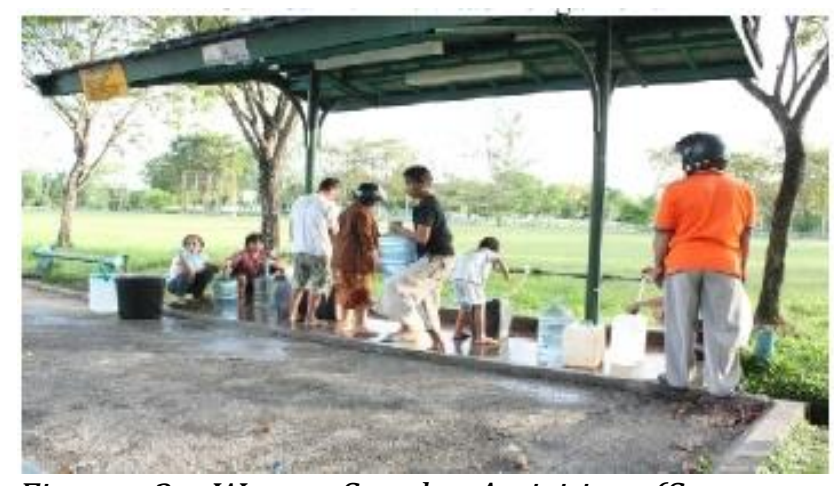

Figure 3. Water Supply Activities (Source: Personal Document).

For the operation of clean water facilities infrastructure, the company is not half-hearted to spend a lot of money. Supervision and research on the quality of water continue to be done so that community is not at risk of a disease. Although this water can be taken freely, there are also regulations set for water taking activity, namely: (1) It is prohibited to bath and wash clothes; (2) It is prohibited to wash vehicles at water supply locations; (3) The schedule of water taking activity is from 06.00 until 18.00 .

\section{Community Development}

Empowerment program is a community development program as an effort to improve the quality of human resources, especially the Bontang City community. Community empowerment programs include support for improving human resources, life skills/basic skills of community and improvement of the community economic capacity. Community empowerment programs can include technical internships at PT Badak LNG, training and certification (welder certification, AutoCAD training, corporate partner training), revolving funds and community infrastructure development support, integrated Rawa Indah market development (development, facilities/coaching, supporting infrastructure, financial support), integrated fishermen fostering (training, boats for fishing groups) revolving funds for small economies, integrated seaweed cultivation (fostering, seaweed farmers' boats, seaweed drying tools), local vendor empowerment. 
Fortune can come from anywhere and skills can be learned slowly. This is something that anyone can experience, no exception for Mulyadi, a Mamuju ethnic man who was born and lived in Bontang. His life changed after he got help from the company in the form of a compost house. He is a former contractor of PT Badak LNG before doing a job as a garbage collector which later the garbage used for compost raw material.

This profession has been undertaken since 2007, while his skills in running a new compost house he learned in 2008. Every day he scavenges and sorts out plastic waste to be recycled into various handicrafts. He made compost raw materials from household waste because household waste is wet and easy to rot. He worked on the compost house for two years.

At first, the local municipal government and the company did not give any help at all, until he submitted a proposal to the company. Less than a month the proposal he submitted was quickly responded by the company. Before any assistance was provided, the company reviewed the location first. Assistance provided by the company was not in the form of funds but in the form of building materials. Development was done by the community and the company only act as contributors of building materials and aid providers. When the compost house just established, there were six neighbors who helped to recycle the waste into compost.

The location of Bontang which is close to the sea and many of the people who work as fishermen make the company inevitably glance at this sector as well. The glance is not to supplement the side income, but the glance is to provide help for the fishermen community to move forward. This sector was not initially glimpsed by the municipal government to be empowered, but the company apparently was smart enough to take steps as a beginner and then followed by local governments. The Company contributed in the form of making a seaweed drying place. Location of the seaweed drying place is in Selangan and Tihi-Tihi area in West Bontang District. To reach this area, people must cross to sea by using water transportation. The aid location of Selangan and Tihi-Tihi is above the sea, like a cage house in the middle of the sea.

This sector is now being undertaken entirely by the municipal government to promote the fisherman's economic life sector and create independence in the community and Bontang city government in order to not depend on the company. This method is used by the company to provoke the creativity of the community and the city government to not depend on and try their own first without having to ask for continued assistance, let alone what is worked by the company for long-term community program in the future, where the company will face post-oil issues.

Indra, secretary of Bontang Lestari Village, West Bontang District explained and affirmed that the company did provide assistance, but he did not really know because most of the programs are not known by the village. He knows the information from the public, for other information usually he and other officials of the village government know from the invitation given by the company related to the inauguration of assistance receipt.

\section{E. Government's Excuses through CSR: A Public Service Claim}

Local government is an institution that is expected to help the community with service. Supposedly, in implement community development everywhere, the municipal authorities are a party that should not be forgotten just because they are one of the stakeholders and community organizers who can directly engage the community.

In the case of the PT Badak LNG community development implementation, the implementation of the social assistance program is considered to neglect the local government apparatus for not being informed of the program given to the community. Several district and village government officials shared matters relating to program implementation as their views on community development implementation.

South Bontang district government staff know enough about the term community development and CSR. The secretary of the district explained some things related to community development activities conducted by PT Badak LNG, there was a review from him that community development is positive but there are still shortcomings in the implementation.

He was well aware in his explanation that if the Bontang City government did not get the social assistance funds from the company, the 
government would not be able to finance the construction of Bontang into what it is today. Moreover, Bontang at least every year experienced many changes seen in terms of infrastructure. According to him with the assistance given, the company helps alleviate poverty, environmental conservation, welfare improvement and competitiveness.

The important and sustained program is the education assistance program in the form of scholarships and foster parents conducted by company employees. He explained that there is a lot of assistance that has been given by the company, but the assistance is not recorded in the district government because usually the company directly plunge into the location and directly deal with the village government. There is a new regulation that village government can manage the households without any intervention from the district government as an institution with a higher position than the village government.

The company does not provide data on what programs have been done in South Bontang District. Information about the existence of social activities is usually known from the invitation letter to participate in the inauguration of the assistance to be provided. The data themselves are usually obtained from the village government, as most social assistance data is provided directly by the company to the village. The limitedness of the district to obtain information about social assistance that has been done by PT BADAK LNG complained by one of the District office staff. It is considered quite disturbing to carry out observation activities and community regulation.

It becomes a bit confusing because the district government must know how much money the company has and it is like the company obliged to give money to the district. By not reducing respect to the district, it is like an event to earn money from the company and it gives a negative impression. The limitation of local government in accessing CSR funds and 'community development' raises another realization of interest, namely the government claims that assistance from PT Badak LNG CSR program is a public service activity by the government to the public. The implementation of the CSR program become a kind of hidden interest encounter arena.

\section{CONCLUSION}

The implementation of CSR and community development in Indonesia is not a new thing. The meaning of CSR is increasingly widespread with the standard setting and implementation of various programs. Implementation policies and program designs are always based on independent corporate decisions. Although the company has the right and authority to plan a social program, it may change due to intervention from other parties, ie stakeholders, local government and the beneficiary community itself.

The design process of the program will always begin with research on the potential recipient of the assistance whether it is relevant and in accordance with the terms, targets, and objectives of the program. The implementation of community development in PT Badak LNG help community face the post-oil and gas situation, where the company experienced a decrease in work effectiveness due to the depleted resources.

The improvement of the community life quality was done with programs that assist the process of human resource development in the field of socioeconomic. Implementation of the community development program conducted by PT Badak has proven its success, visible from the phenomenon of community life and Bontang development is getting better and growing as long as the company started doing community development. The program also provided lessons for the community to become more aware of the environment and protect the natural environment.

The influence of community development has a major role in the adherence of social relationships in the community. Bontang is one example of a city that has a diversity of ethnic groups, even so, life is harmonious. Through the creation of a situation and a sense of belonging to ownership, the community development program indirectly influences the community to unite in order to create a better life. The sense of the program's implementation then makes the community unconsciously participate in the pattern of cultural life in the company. It is good with awareness of the sense of belonging of the company, such as taking care of the factory, maintaining the public facilities provided by the company.

The bad thing is they try to force themselves to follow the life culture of employees who have a higher economic level. The implementation of community development by PT Badak LNG 
certainly reap a lot of responses in the community. There are positive and negative responses, but on the other side what has been done by the company began to get a belief in the hearts of the people of Bontang. The image of the company that arises in society is quite good, as evidenced by more people who know the company's social assistance activities than those who do not know. Although the company has gained a good image in society, it should not be considered trivial and become snobby. Any suggestion and criticism should be addressed for better learning process so that other social program implementation can be done more perfectly.

In every implementation of the CSR program, the company should pay more attention to the selection of assistance so as not to become extravagant. Every program that has been implemented should be adequately evaluated in order to become a lesson for creating better programs in the future. One thing that should not be forgotten is that the implementation of the program should also be better socialized to the government and the community. So that the program can be better understood and created a good cooperation relationship with the stakeholders.

\section{ACKNOWLEDGEMENT}

First of all, thanks to PT Badak LNG, Bontang City Government, and Bontang community who are very helpful to provide highly strategic related information. Furthermore, the authors are grateful to the committee of ICOSOP 2017 which has allowed this script also presented and published as a series of academic narratives from various academics who participated in the conferencee

The authors are also grateful to several academic institutions that contribute to the participation of authors in the ICOSOP 2017 conference in Medan, North Sumatra. They are the LPDP of the Republic of Indonesia which is very helpful in provided funding support for education and publication for the author as one of the recipients of doctoral scholarship (BUDI-DN
2017). Then Gadjah Mada University and Padjadjaran University as the institution where the authors carry out the study. The University of Malikussaleh, the institution where the author serves as a lecturer at the Department of Anthropology, Faculty of Social and Political Sciences.

Lastly, we are grateful to parents, family, friends and colleagues who have supported the our scientific step until now.

\section{REFERENCES}

[1] A.B. Susanto, Reputation-Driven Corporate Social Responsibility (Strategic Management Approach in CSR). Jakarta: Esensi, 2009.

[2] D. Matten and J. Moon, "Implicit and Explicit CSR: A Conceptual Framework for a Comparative Understanding of Corporate Social Responsibility," Academy of Management Review, vol. 33, No. 2, pp. 404424 (2008).

[3] H.S. Ahimsa-Putra, "Fenomenologi Agama: Pendekatan Fenomenologi untuk Memahami Agama", Jurnal Walisongo, vol. 20, No. 2, pp. 271-304 (November 2012).

[4] M. Amri, CSR Untuk Penguatan Kohesi Sosial. Jakarta: Indonesia Business Links, 2008.

[5] M. Fajar ND, Tanggung Jawab Sosial Perusahaan di Indonesia: Studi tentang Penerapan Ketentuan CSR pada Perusahaan Multinasional, Swasta Nasional dan BUMN di Indonesia. Yoyakarta: Pustaka Pelajar, 2010.

[6] E. Suharto, Membangun Masyarakat Memberdayakan Rakyat: Kajian Strategis Pembangunan Kesejahteraan Sosial dan Pekerjaan Sosial. Bandung: Refika Aditama, 2006.

[7] E. Suharto, Pekerjaan Sosial di Dunia Industri Memperkuat Tanggung Jawab Sosial Perusahaan (CSR). Bandung: Refika Aditama, 2007.

[8] P.R. Waagstein, "The Mandatory Corporate Social Responsibility in Indonesia: Problems and Implications," Journal of Business Ethics, vol. 98, No. 3, pp. 455-466 (February 2011). http://www.jstor.org/stable/41476143 